\title{
Comparison of three soil cultivation method in case of grape
}

\author{
Göblyös, J. \& Zanathy, G. \\ Corvinus University of Budapest, Department of Viticulture judit.goblyos@uni-corvinus.hu
}

\begin{abstract}
Summary: Our results show that the different cultivation methods have effect on the yield and the grape quality as well. In 2008 and 2009 the straw mulch proved to be the best solution regarding the yield. The soil compaction was reduced in these plots and the photosintetical activity was also higher. Straw mulch could conserve the moisture content of the soil. The less yield was observed in case of barely covered vines and also the vegetative growth of the grape was less intensive in case of these vines, but it seems to be contributed to the conformation of suitable microclimate for Botrytis infection.
\end{abstract}

Key words: grape, soil cultivation, straw mulch

\section{Introduction}

Soil cultivation is one of the most important questions of the viticulture. It has an effect not only on the soil, but indirectly on the plants as well. Therefore it is really relevant to choose the proper cultivation method. Also in case of integrated and organic farming is advanced to apply these environment friendly methods.

In case of vineyards is the soil cultivation also important, especially when the plantation is located in steep slopes. Such kind of erosion, which can be caused by heavy rainfalls or also by frequent mechanical soil cultivation, is a major problem. So soil cultivation method has to be chosen considering this. A suitable soil cultivation method improves the soil structure: compaction, erosion, nutrient losses can be reduced. It makes better conditions in the soil environment for the existing soil organisms, as follows it increases soil biological activity and the organic matter content of the soil can be preserved. The moisture content of the soil depends also on the cultivation method. The preservation of soil moisture is especially important, in that kind of areas where the precipitation is less than $500 \mathrm{~mm} /$ year and principally from June to August, when the evapotranspiration is greater than the precipitation, like in Hungary (Bauer et al., 2004). Today, the farmers have to face also with the effects of climate change, so the reservation of the soil moisture and the protection against erosion in case of heavy rainstorms is really important. The growth of the roots is influenced by the structure of the soil; hereby the growth of the grape is related to the compaction and to the moisture content of the soil, too. The looser the soil is the longer the roots of the vine are (Wheaton et al., 2007). Nutrient uptake of the grape is affected by the soil compaction, the moisture content and the soil temperature. For example between the high soil temperature and $\mathrm{N}, \mathrm{K}, \mathrm{Ca}, \mathrm{Mg}$ uptake is a positive correlation (Bogoni et al., 1995). Several abnormal circumstances in the soil, for example lack of water can cause stress on the plants, which influences the growth and the yield of the plants negatively (Fardossi, 2001).

One of the most often used soil cultivation methods in vineyards is mechanical cultivation. But when it is used too often or inadequate negative effects can be observed: decaying soil structure, erosion, nutrient losses, dry soil affected by greater evapotranspiration (Bauer et al., 2004; Aljibury et al.,1972; Dijck et al., 2002). Mechanical soil cultivation results through the long term traffic- topsoil and subsoil compaction below the frequent tillage depth (Ferrero et al., 2005; Zanathy 2006).

Covering methods are ecological soil management techniques. As soil covering several materials (straw, reed, sedge, etc....) or cover crops can be used. Straw mulch is a relatively cheap and easy available material. Application of mulch has a lot of agronomic advantages, including the control of weeds and erosion, improvement in soil physical structure. The presence of mulch eliminates the need for frequent soil tillage in agroecosystems. It prevents the soil like an umbrella by heavy rainstorms (Schuch, 1981; Rinaldi et al., 2000; Varga, 2004). The prevention of the soil is important, because the soil moisture in the whole profile depend primarily on the intensity of rainfall, not on the total amount of it. At high intensities soil moisture increases only in the surface layer, but no significant increases were observed in deeper layers, where most of the roots are found. Under low intensity rainfalls, the increase in soil water content occurred in the whole profile (Ramos et al., 2006). The water budget of the soil improves due to the better structure and the straw reduces water loss by evaporation. It enhances the soil environment for existing soil organisms by improving soil nutrient availability and reducing soil temperature fluctuations (Jacometti et al., 2007). When the straw decays it adds nutrients to the soil, but because its $\mathrm{C}: \mathrm{N}$ ratio is wide, additional $\mathrm{N}$ is needed. Otherwise the lack of $\mathrm{N}$ causes pentosan effect (Fox, 1981). 
Beside straw or other mulch materials, several crops can be used. Permanent or only in certain seasons covering crops, legumes or non legumes are appropriate to cover the soil between the rows. Cover crops compete with weeds, prevent erosion and soil compaction and in addition, they increase the complexity of agroecosytems. The soil structure and soil biological activity will improve (Varga, 2007; Diófási, 2000). They facilitate to filter the water into the soil. It has an effect on the nutrient content of the soil, especially when a leguminous plant is used, because of the biological fixation of atmospheric N (Bauer et al., 2004; King et al., 2005; Wheaton et al., 2007). Cover crops have also negative effects on the vine performance; compete for water and nutrients in the soil with vine. Places, where precipitation is not high enough are not suitable for permanent cover crops, because of the great use of water. In this cases grapes are stunted, lower vine performance can be observed. The vegetative growth is reduced, but it can have also positive effects. Because of the lower canopy density, the microclimate of the plantation will change, the vapor content of the air will be lower, and because of this the infection of the grape with fungal diseases, for example Botritys cinerea, is reduced (Monteiro et al., 2007; Steinberg, 1981; Varga, 2000). In some cases it can be disadvantageous, for example in the Tokaj wine region of Hungary, where the noble rot of the berries caused by Botritys cinerea is important to gain Aszú wine. Infection of Botritys requires moist conditions, but later for the rotting period, it needs drier climate. If the weather stays wet, grey rot of the bunches can be observed (Lehoczky, 1968). There is an increased light penetration in the thin canopy, so the titratable acidity of the berries can be reduced and the sugar content will improve (Ingels et al., 2005).

\section{Materials and methods}

The experiment was set up in the Tokaj-wine region in 2007, the measurements were taken in 2008-2009. Three soil cultivation methods were compared: mulching with straw, barely cover crop (Hordeum vulgare L.convar. vulgare MSF.) and mechanical cultivation. The study was carried out on Royat cordon vines (with $1 \times 1,8 \mathrm{~m}$ row and vine spacing). The investigated variety was 'Hárslevelü' clone K.9 grafted in Teleki 5.C. rootstocks. Every treatment is located in five rows, in four replications per treatment. The plantation is settled in a steepslope area on loess soil in the site of Hétszőlő (Hárslevelü) where the prevention of erosion is especially important.

In case of mechanical cultivation, next to the autumn plough the soil was cultivated three times. On the plots with barely cover crop, after the seed bed preparing and sawing, wasn't any cultivation. The straw mulch was laid down in 2007, and it was renewed in May 2008 and 2009.

The compaction of the soil was measured from June to September in 2008, in every month, with a ScoutDat 900 penetrometer. The $\mathrm{NO}_{2}+\mathrm{NO}_{3}$ content of the soil was measured from March to September, in the last pentade of the months in 2008-2009. The soil samples were collected from the $0-30 \mathrm{~cm}$ and $30-60 \mathrm{~cm}$ soil layer. The transpiration rate and the net $\mathrm{CO}_{2}$ assimilation were measured with an infrared gas analisator (LCi, ADC Bioscientific Ltd.) in case of 10 stocks per treatment. The yield was harvested both years in October. Next to the yield/vine, the percent of the noble rotted berries was determined from 100 bunches per every treatment.

\section{Results}

Regarding the soil compaction, in the deeper soil layers higher values were measured -more than $3500 \mathrm{kPa}$ in some cases - like in the upper layers. This can be caused by the regular through pass of the machines. This compaction can't be raised not either by the mechanical cultivation, because is has an effect only in the upper 15-20 cm layers. The compaction will be always harder with the months, except in case of the straw mulched plots, where the compaction was lower in September due to the positive effect of the mulch (1. Figure).
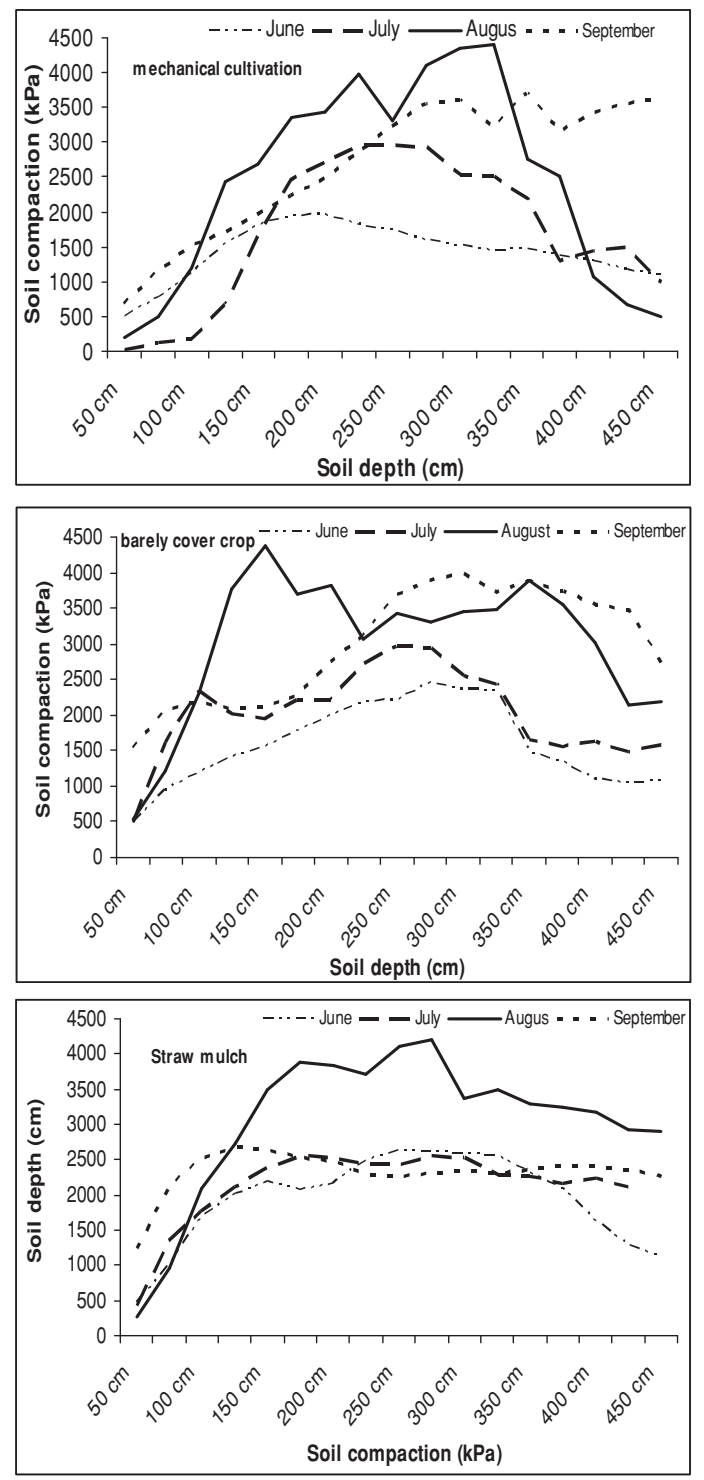

Figure 1. Soil compaction, depending on the soil depth in case of mechanical cultivation, barely cover crop and straw mulch, from June to September (Tokaj, 2008) 
Comparing the nitrite and nitrate content of the soil the higher values were measured in case of the mechanical cultivated interrows, because this cultivation method helps to decay the organic materials in the soil. This could be observed in 2009, when after the seed bed preparing in March, the nitrogen content of the soil was higher in April, in case of the plots with barely cover crop. The lower values under the straw mulch and on the plots with barely cover crop can be explained with the pentosan effect, caused by the decaying straw and the nitrogen use of the cover crop, respectively.
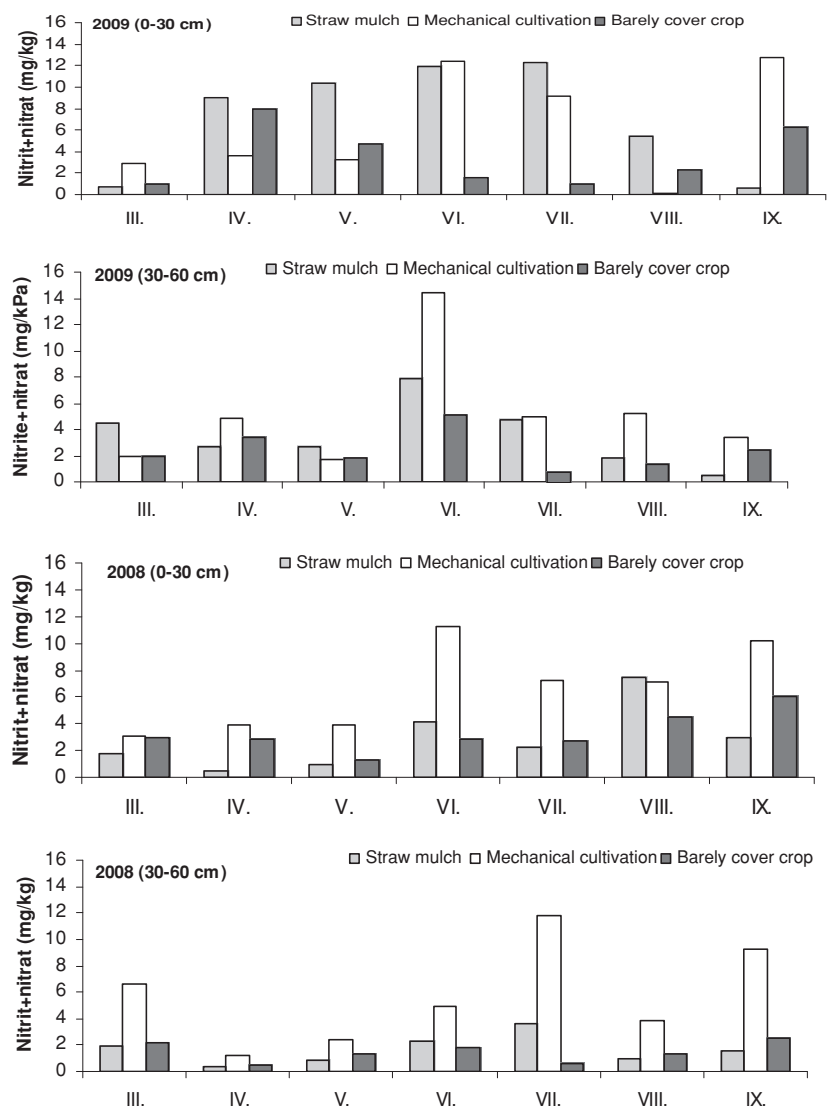

Figure 2. The nitrite and nitrate content of the soil in the $0-30 \mathrm{~cm}$ and $30-60$ cm depth, from March to September (Tokaj, 2008-2009)

The figures show that the high nitrogen content in the upper $(0-30 \mathrm{~cm})$ layer reduced from June to July in 2008 on the mechanical cultivated plot (Figure 2.). This higher $\mathrm{NO}_{2}+\mathrm{NO}_{3}$ content could be observed in July in the $30-60 \mathrm{~cm}$ soil layer. Probably it can be explained with the mechanical cultivation in the end of June and the extreme amount of precipitation fallen in this period $(68,7 \mathrm{~mm})$. Due to the cultivation and the precipitation, the nutrients went down in the deeper layers. Unfortunately, in this layers are the nutrients not so easy available for the vines. Because of this is the too often used and deep mechanical cultivation not advised during the vegetation period.

During the observation of the gas exchange parameters also differences could be observed between the treatments. The net $\mathrm{CO}_{2}$ assimilation of the vines in the straw mulched plots was higher, like the other treatments. The lower values were measured in case of the mechanical cultivated plots. The results show, that during the measurements in 2008 August, there wasn't notable water stress, because the net $\mathrm{CO}_{2}$ values didn't go under $4 \mu \mathrm{mol} \mathrm{m} \mathrm{m}^{-2} \mathrm{~s}^{-1}$ (Figure 3.).
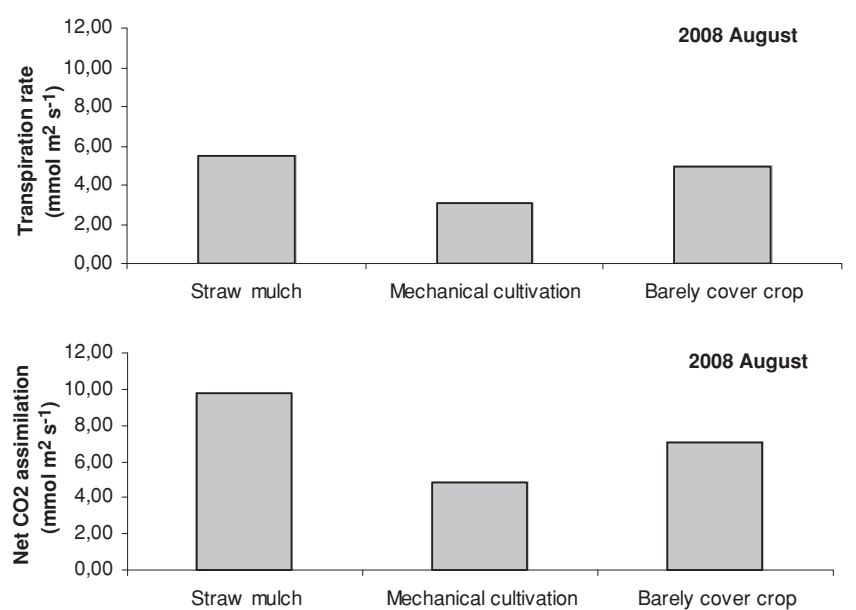

Figure 3. Changes of the net $\mathrm{CO}_{2}$ assimilation and transpiration rate on plots treated by different soil cultivation methods
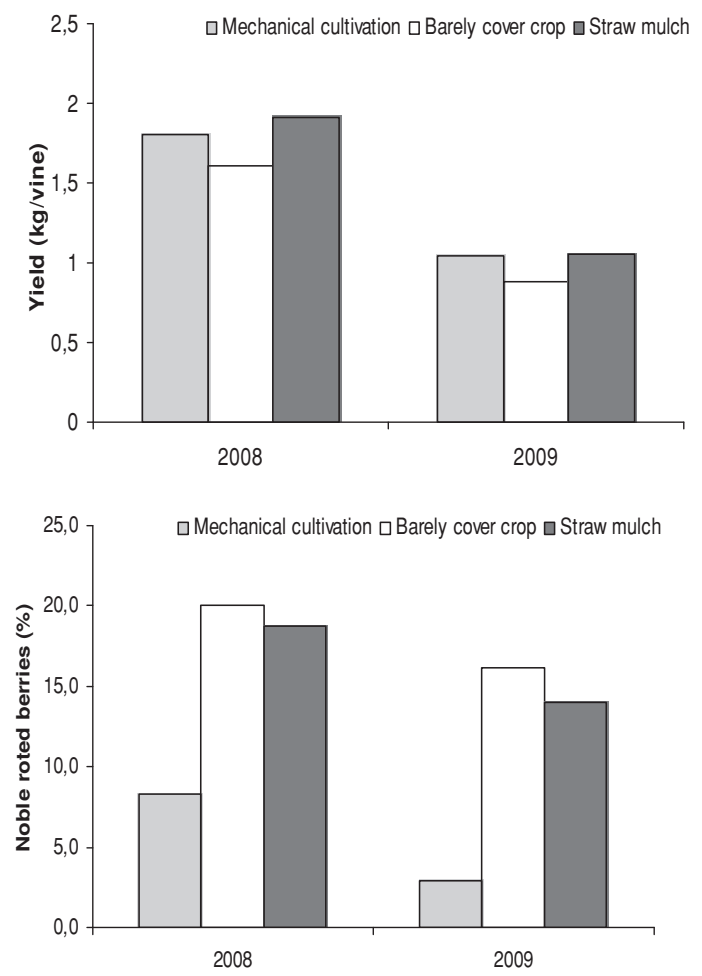

Figure 4. Yield and percent of noble rot between one bunch on plots treated by different soil cultivation methods in Tokaj

Comparing the yield and the percent of noble rotted berries, differences could be observed between the treatments in both years. The greater yield was measured on the plots with straw mulch, the less on the barely covered plots, in both years.

The percentage of the rotted, Botritys infected berries was counted within the bunches. The more rotted berries 
were by the bunches from barely covered plots observed, and the grapes from the mechanical cultivated rows contained the less infected berries (Figure 4.).

\section{Conclusions}

Our results show that the different cultivation methods have an effect on the yield and the grape quality too. Regarding soil compaction, photosynthetic activity and the yield, the straw mulch proved to be the best soil cultivation method. The percent of the noble rotted berries, which is the most important in Tokaj, regarding the grape quality, was the higher in the rows with barely cover crop.

\section{References}

Aljibury F. \& Christensen P. (1972): Water penetration of vineyard soils as modified by cultural practices. Am. J. Enol. Vitic. 23: 1 35-38.

Bauer, K., Fox, R. \& Ziegler, B. (2004): Moderne Bodenpflege im Weinbau. Österreichischer Agrarverlag, Leopoldsdorf.

Bogoni, M., Panont, A., Valenti, L. \& Scienza, A. (1995): Effects of soil physical and chemical conditions on grapevine nutritional status. Acta Horticulturae 383 (Nutrition of decidous fruit plants), 299-303.

Dick, SJE. \& Asch, T.W.J. (2002): Compaction of loamy soils due to tractor traffic in vineyards and orchards and its effect on infiltration in southern France. Soil Tillage Research. 63. 141-153.

Diófási, L., Csikászné, K.A., Bíróné, T.Gy. \& Bene, L. (2000): Vízgazdálkodás, erózió elleni védelem hegyvidéki szőlőkben. LippayOrmos-Vas Tudományos ülésszak kiadványa, 2000. nov. 6-7. 518.

Fardossi, A. (2001): Einfluss von Stressfaktoren auf die Weinrebe. Der Winzer 1/2002 12-13.

Ferrero, A., Usowicz, B. \& Lipiec, J. (2005): effects of tractor traffic on spatial variability of soil strength and water content in grass covered and cultivated sloping vineyard. Soil Tillage and Research, 84: 127-138.

Fox, R., (1981): Abdeckmaterialen für Steillagen. Der Deutsche Weinbau. 25/26: 1075-1076.
Ingels, A.C., Scow, K.M., Whisson, D. A. \& Drenovsky, R.E. (2005): Effects of cocer crops on grapevines, yield, juice, composition, soil microbial ecology, ang gopher activity. Am. J. Enol. Vitic. 56. (1): 19-30.

Jacometti, M.A., Wratten, S.D. \& Walter, M. (2007): Management of understroey to reduce the primary incolum of Botrytis cinerea: Enhancing ecosystem services in vineyards. Biological Control, 40: 57-64.

King, A.P. \& Berry, A.M. (2005): Vineyard nitrogen and water status in perennial clover and bunch grass cover crop systems of California's central valley. Agriculture, Ecosystems and Environment, 109: 262-272.

Lehoczky-Reichart (1968): A szőlő védelme Mezőgazdasági Kiadó Budapest

Monteiro, A. \& Lopes, C.M. (2007): Influence of cover crop on water use and performance of vineyard in Mediterranean Portugal. Agriculture, Ecosystems and Environment. 121: 336-342.

Ramos, M.C. \& Martínez-Casanovas, J.A. (2006): Impact of land levelling on soil moisture and runoff variability in vineyards under different rainfall distributions in a Mediterranean climate and its influence on crop productivity. Journal of Hydrology, 321: 131-146.

Rinaldi, M., Rana, G. \& Introna, M. (2000): Effects of partial cover of durum wheat straw on soil evaporation in a semi arid region. Acta Horticulturae 537 (Proc. $3^{\text {rd }}$ IS on Irrigation Hort. Crops), 159-162.

Schuch, M. \& Jordan, F. (1981): Ergebnisse zehnjahriger Erosionsschutzversuche im Steillagenweinbau in Franken. Der Deutsche Weinbau, 25/26: 1081-1082.

Steinberg, B. (1981): Kurzzeit-und Dauerbegrünung in Hang - und Steillagen. Der Deutsche Weinbau, 25/26/1981 1070-1074.

Varga, P. \& Májer, J. (2004): The use of Organic Wastes for Soilcovering of Vineyards. Acta Horticulturae, 652: 191-197.

Varga, P., Májer, J. \& Németh, Cs. (2007): Tartós és időszaki növénytakarásos eljárások a szőlöültetvények talajmüvelési rendszereiben. Lippay-Ormos-Vas Tudományos ülésszak kiadványa 2007. november 7-8.

Wheaton, A.D., McKenzie, B.M. \& Tisdall, J.M. (2007): Management to increase the depth of soft soil improves soil conditions and grapevine performance in an irrigated vineyard. Soil Tillage Res.

Zanathy G., (2006): A szőlötalajok tömörödéséről tömören, Agro Napló 2: 76-77. 